\title{
Effect of Method Additions with and without Soaking in Phosphatic Fertilizers on Faba Bean Plant El-Ghamry, A. M. ${ }^{1}$; E. M. El-Naggar ${ }^{2}$ and M. M. Shams El-Dean ${ }^{2}$ \\ ${ }^{1}$ Soils Department, Faculty of Agriculture, Mansoura University, Egypt. \\ ${ }^{2}$ El-Delta Company for Fertilizers and Chemical Industries (ASMEDA) in Talkha, Egypt.
}

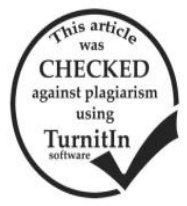

\section{ABSTRACT}

A pot experiment was conducted at the Experimental Farm of Fertilizers Development Center, El-Delta Company for Fertilizers and Chemical Industries (ASMEDA) in Talkha, Dakahlia Governorate, Egypt during the winter season of 2015/2016 to enhancement of phosphate fertilizer using different methods of application. In addition, determining the optimum methods of application of phosphorus fertilizers for growth, yield and yield components and the availability of nutrients for faba bean Giza 716 cultivar .The experiments was carried out in a factorial experiment in a complete randomized block design with three replications. The results show that the most efficient treatment was mixing single- superphosphate (6.34 P) with soil with soaking seeds in a saturated solution of single- superphosphate (6.34 P) MSM soaking [.These results may be due to the fact that delayed phosphate fertilization after the early growth stages tends to reduce plant uptake of phosphorus, which leads to low concentration of phosphorus in grains.

Keywords: Faba bean, Phosphorus fertilizer, Soaking, methods of application, Yield, Quality, Nutrients uptake.

\section{INTRODUCTION}

Phosphorus $(\mathrm{P})$ is one of the major nutrients required for plant growth and reproduction. Phosphorus, such as carbon and nitrogen is an essential element in all living systems. It is often referred to phosphorus as the "energizer" since it helps store and transfer energy during photosynthesis. Phosphorus is required to synthesize DNA molecules (DNA, RNA). Also A vital bioenergy component of the adenosine triphosphate (ATP) molecule as the phosphate groups of water form and key elements in cell membranes (Marschner, 2012). Crops deficient in phosphorus tend to develop slower, exhibit limited growth potential, and yield less than expected (Johnston, 2001). Phosphorus is often found in fixed chemical forms that cannot immediately be absorbed by plants.

Faba bean (Vicia faba L.) is grown world-wide as a protein source for food and feed. Its seeds are high in protein, vitamins, and minerals. At the same time faba bean offers ecosystem services such as renewable inputs of nitrogen into crops and soil enhancing its richness via biological $\mathrm{N}_{2}$ fixation and a diversification of cropping systems (Jensen et al., 2010). Faba bean is considered one of the most important seed legume crops grown in winter season at different types of soils in Egypt. Production of faba bean in Egypt is still limited and falls to face the increasing local consumption the crop, this is related to the cultivated area by faba bean in Egypt is relatively small and decreased dramatically in last decade. This is due to the strong competition between faba bean and other strategic winter season crops such as wheat and clover on the limited arable land in Nile valley and Delta.

Egyptian Government is pressing hard to increase the yield and quality of faba bean plant through improving agricultural practices such as enhancement of phosphate fertilizer using different methods of application under different Egyptian soil conditions.

The method of application of phosphorus fertilizer should be taken into account to obtain profitable results in crop growth. Phosphorus fertilizer could be used broadcasting and incorporate prior to seeding of legume crops. However, it could use placement method which positively affect the phosphate recovery and yield obtained (Turk and Tawaha, 2001). Slaton et al. (2002) showed that broadcast application of phosphorus fertilizer to the soil surface between seeding and active tillering were equally effective at increasing rice yields and optimizing phosphorus uptake on the P deficient soils. Turk and Tawaha (2002) found that methods of phosphorus application (banding and broadcasting) had only a significant effect on seed yield and seed weight per plant. Highest yields were obtained by application of phosphorus fertilizer as drilled with the seed after cultivation (banded). El-Ghamry et al. (2009) showed that adding half the recommended phosphorus fertilization rate at sowing and the other half before the first irrigation was the most efficient treatment to enhance phosphorus fertilizer use efficiency, contributing to an increased uptake of phosphorus by cowpea, reflected in the higher phosphorus concentration in the grains. Increased phosphorus uptake also caused an increase in the nitrogen and potassium concentrations in cowpea grains, whereas the zinc and iron concentrations decreased. Esmail and Miran (2012) indicated that the highest values of plant height, dry matter weight, yield, number of active nodules, phosphorus and protein content were recorded from combination application of 100 mg phosphorus per $\mathrm{kg}$ soil and application of $1 / 2$ of applied phosphorus to the soil and foliar application of other half.

Therefore, the present work aims to enhancement of phosphate fertilizer user efficiency using different methods of application. In addition, determined the optimum methods of application of phosphorus fertilizers for growth, yield and yield components and the availability of nutrients for faba bean.

\section{MATERIALS AND METHODS}

\section{Materials of study}

Surface soil samples $(0-30 \mathrm{~cm})$ were collected from the Experimental Farrm of El-Delta Company for Fertilizers and Chemical industries (ASMEDA) in Talkha, Dakahlia Governorate, Egypt. Physical and chemical characteristics of the investigated soil were determined according to (Dewis and Fertias, 1970). Hesse (1971). Faba beans (Giza 716) were kindly obtained from Agricultural Research Station in Sakha City, Kafr El - Sheikh Governorate Seeds were then inoculated with Okadin ;( Rhizobium sp.).at a rate of $100 \mathrm{~kg}$ per fidden, $1.2 \mathrm{gm}$ per pot. fidden using inoculation of seeds with rhizobium as an adhering material.

Method of Study

A pot experiment was conducted at the greenhouse conditions of the fertilizers Development Department, El- 
Delta Company for Fertilizers and Chemical industries (ASMEDA) during the winter season of 2015/2016 to find out the optimum method for applying P-fertilizers on the yield outcome and yield components of faba beans. The uptake of NPK by the grown plants was also a matter of concern in the current research. To attain these aims, plastic pots $(30 \mathrm{~cm}$ diameter $\times 35 \mathrm{~cm}$ length) were uniformly packed with soils equivalent to $12 \mathrm{~kg}$. Physical and chemical characteristics of the investigated soils are presented in Table 1. Pots were then cultivated with bean seeds at a rate of 8 seeds per pot on the $28^{\text {th }}$ of October 2015. Plant density was adjusted 20 days latter, by thinning plants to leave only 5 healthy plants in each pot. Soil moisture was maintained at the field capacity throughout the experimental period. All pots received NPK fertilizers at the recommended rate of the Ministry of Agriculture and Land Reclamation. Nitrogen was applied in the form of ammonium nitrate $(33.5 \% \mathrm{~N})$ at a rate of $15 \mathrm{mg} \mathrm{N} \mathrm{kg}^{-1}$ which is equal to $0.18 \mathrm{~g} \mathrm{pot}^{-1}$ as a starter dose before thinning to stimulate the activities of Okadin ;( Rhizobium sp.) bacteria. Potassium sulphate $(40 \% \mathrm{~K})$ was amended at a rate of $100 \mathrm{~g} \mathrm{~kg}^{-1}$ which is equal to $1.2 \mathrm{~g} \mathrm{pot}^{-1}, 43$ days after seedling and before the second irrigation. Mono-calcium phosphate $(6.34 \% \quad \mathrm{P})$ was amended at a rate of $150 \mathrm{~g} \mathrm{~kg}^{-1}$ which is equal to $1.80 \mathrm{~g} \mathrm{pot}^{-1}$; however, the method of application was a matter of concern in the current study. The experiment was carried out in complete randomized block design (CRBD) with three replicates. The first factor was the effect of soaking seeds for 2 hours in a saturated solution of mono-calcium superphosphate $\left(63.4 \mathrm{~g} \mathrm{P} \mathrm{kg-1)}\right.$ prepared at a rate of $100 \mathrm{~g} \mathrm{~L}^{-}$ ${ }^{1}$, afterwards, seeds were air dried. The second factor was the timing of phosphate application i.e. before sowing and after seedling emergence. Plants were sampled from each treatment at 45 and 135 days after sowing to measure the following growth parameters i.e. plant height, total chlorophyll content (SPAD, assessed in the third leaf of main stem by SPAD-502), fresh and dry weights. Plants were harvested at the physiological maturing growth stage, attained at 203 days after sowing. The following growth parameters were determined seed yield per plant, number of pods per plants, pod weight per plant, number of seeds per plant, 100-seed weight. The plant material was then oven dried on $70 \mathrm{C}$ for $48 \mathrm{~h}$; afterwards, the dry weights were determined. The dried materials were grounded, digested by an acid mixture of sulfuric and perchloric acid as described by Peterburgski (1986). The oven dry plant samples were ground and wet digested by sulphuric perchloric acid mixture as described by Peterburgski, (1986). Total N, P, K, $\mathrm{Fe}, \mathrm{Zn}$ and $\mathrm{Mn}$,Total nitrogen (\%), Total phosphorus percentage $(\%)$, Potassium percentage $(\%)$ and crude protein percentage $(\%)$ was determined in the dry seeds by determination of $\mathrm{N} \%$ and was multiplied in 5.75 according to AOAC (2007). Total micronutrients (Fe, $\mathrm{Zn}$ and $\mathrm{Mn}$ ) contents (ppm) were determined according to Mathieu and Pieltain, (2003).

\section{Data Analysis}

All obtained data were subjected to the statistical analysis according to the technique of analysis of variance (ANOVA) for the factorial experiment in complete randomized block design (CRBD) as published by Gomez and Gomez, (1984) by means of Co-STATE Computer Software. Least significant of difference (LSD) method was used to test the differences between treatment means at $5 \%$ level of probability as described by Snedecor and Cochran, (1980).

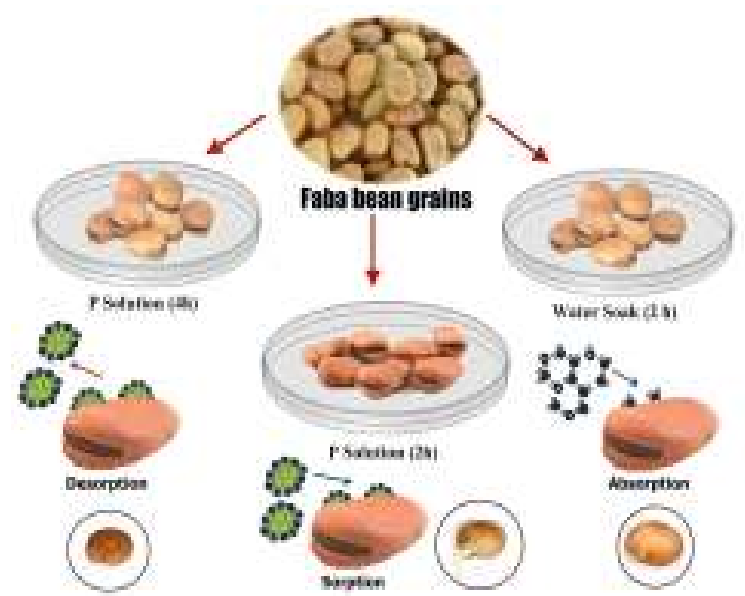

Effect of soaking in water and single-superphosphate $(6.34 \%$ P) on faba bean seeds.

Table 1. Physical and chemical properties of the studied soil before faba bean sowing.

\begin{tabular}{|c|c|c|c|c|c|c|c|c|c|c|c|}
\hline \multicolumn{5}{|c|}{ Particle sizze distribution \% } & \multirow[b]{2}{*}{$\begin{array}{l}\text { Texture } \\
\text { class }\end{array}$} & \multirow[b]{2}{*}{$\underset{\left(\mathrm{g} \mathrm{kg}^{-1}\right)}{O M}$} & \multirow[b]{2}{*}{$\begin{array}{l}\mathrm{CaCO}_{3} \\
\left(\mathrm{~g} \mathrm{~kg}^{-1}\right)\end{array}$} & \multirow[b]{2}{*}{$\begin{array}{c}\text { F.C } \\
\%\end{array}$} & \multicolumn{3}{|c|}{ Available (mgkg $\left.{ }^{-1}\right)$} \\
\hline $\begin{array}{l}\text { C. Sand } \\
(\%)\end{array}$ & $\begin{array}{c}\text { F. Sand } \\
(\%)\end{array}$ & $\begin{array}{l}\text { Silt } \\
(\%)\end{array}$ & $\begin{array}{l}\text { Clay } \\
(\%)\end{array}$ & & & & & & $\mathbf{N}$ & $\mathbf{P}$ & $\mathbf{K}$ \\
\hline 1.7 & 19.8 & 28.4 & 50.1 & & clay & 11.0 & 40.0 & 35.0 & 48.5 & 3.90 & 189.5 \\
\hline \multirow{3}{*}{$\mathrm{pH}^{*}$} & \multirow{3}{*}{$\begin{array}{c}\mathrm{EC}^{* *} \\
\mathrm{dS} \mathrm{m}^{-1}\end{array}$} & \multicolumn{10}{|c|}{ Soluble ions conc. $\mathrm{meg} / 100 \mathrm{~g}$ soil ${ }^{* * *}$} \\
\hline & & \multicolumn{6}{|c|}{ Cations } & \multicolumn{4}{|c|}{ Anions } \\
\hline & & & & $\mathrm{Mg}^{+1}$ & $\mathrm{~N}$ & & $\mathrm{~K}^{+}$ & $\mathrm{CO}_{3}{ }^{-}$ & $\mathrm{HCO}_{3}$ & $\mathrm{Cl}^{-}$ & $\mathrm{SO}_{4}$ \\
\hline 7.80 & 1.19 & & & 1.00 & 6. & & 1.00 & -- & 0.90 & 5.40 & 5.60 \\
\hline
\end{tabular}

C. sand: Coarse sand $\quad$ F. sand: Fine sand F.C: Field capacity

* Soil pH was determined in soil paste.

** Soil Electrical Conductivity (EC) was determined in soil paste extract.

*** Soluble ions were determined in 1:2.5 soil water suspensions.

\section{RESULTS AND DISCUSSION}

Plant growth parameters and yield components as affected by soaking and time of $P$ treatment

Data presented in Table 2 show that the vegetative growth parameters of faba beans plant high flowering and harvest $(\mathrm{cm}), 100$ Seed dry weight $(\mathrm{g})$ and Pods dry weight (g) ) Were significantly affected by soaking seeds in $\mathrm{P}$ solution as well as the time of P-application. Soaking seeds in $\mathrm{P}$ solution increased significantly the fresh and dry weights of plants. Likewise, amending soils with P-fertilizer increased significantly the fresh and dry weights of plants. The positive effects for both seed soaking and time of Papplication were investigated by Sorour (1993) and AbdelHaleem (1994). It is well known that phosphorus plays important roles in plant growth and cell division 
(Hashemabadi, 2013), thus plant height increased with application of $\mathrm{P}$ amendment (Afzal et al., 2010). However, the interactions between these two factors. P-fertilizer * seed soaking were also of significant effect. Although, soaking seeds in $\mathrm{P}$ solution decreased plant height for those grown in soils not amended with $\mathrm{P}$ or those received P-fertilizer after the emergence of seedling; however, the soaking treatment seemed to be of significant affect only if the soaked seeds were grown in soils amended with $\mathrm{P}$ before sowing seeds (compared with the un-soaked ones). There is no wonder to find out that the pod yield per plant increased when soils amended with phosphate before seedling compared with those received $\mathrm{P}$ after seedling emergence. However, 100seed weight seemed to be relatively lower in the first treatment than in the second one.

Table 2. Vegetative growth characters (plant high flowering and harvest $(\mathrm{cm}), 100$ Seed dry weight (g) and Pods dry weight (g) of faba bean as affected by soaking seed treatments and the time of phosphorus application.

\begin{tabular}{|c|c|c|c|c|c|c|c|c|}
\hline & Cont & DPM & MSM & Mean & Cont & DPM & MSM & Mean \\
\hline & \multicolumn{4}{|c|}{ P.H flowering cm } & \multicolumn{4}{|c|}{ P.H harvest $\mathrm{cm}$} \\
\hline Without Soak & 35.1 & 41.75 & 36.3 & 37.72 & 61.72 & 66.63 & 62.32 & 63.5567 \\
\hline Soak & 34.9 & 39.47 & 44.4 & 39.59 & 56.87 & 65.8 & 79.33 & 67.3333 \\
\hline Mean & 35 & 40.61 & 40.35 & 38.65 & 59.295 & 66.215 & 70.825 & 65.445 \\
\hline LSD5\% & \multicolumn{4}{|c|}{1.41} & \multicolumn{4}{|c|}{1.16} \\
\hline & \multicolumn{4}{|c|}{100 Seed dry weight $(\mathrm{g})$} & \multicolumn{4}{|c|}{ Pods dry weight (g) } \\
\hline Without Soak & 63.31 & 68.71 & 77.64 & 69.8867 & 61.15 & 91.12 & 81.02 & 77.7633 \\
\hline Soak & 90.42 & 121.88 & 108.52 & 106.94 & 45.08 & 60.48 & 80.21 & 61.9233 \\
\hline Mean & 76.865 & 95.295 & 93.08 & 88.4133 & 53.115 & 75.8 & 80.615 & 69.8433 \\
\hline LSD5\% & \multicolumn{4}{|c|}{2.84} & \multicolumn{4}{|c|}{3.74} \\
\hline
\end{tabular}

Elemental composition of the grown plants:

Data in Table 3 show that the chemical composition of faba bean was significantly affected by seed soaking as well as the time of $\mathrm{P}$ application. Generally, P-application increased NPK contents in faba plants. Similar results indicate that phosphorus concentration in seeds of faba beans was directly related to the rate of the applied P-fertilizer (Henry et al., 1995). Concurrent increases in N, K, Fe and $\mathrm{Zn}$ contents occurred within the investigated plant parts i.e. shoot and seed.This might be attributed to the effect of phosphorus on stimulating root growth (Wen et al., 2016) and exhibiting strong physiological root plasticity (Zhang et al., 2016), besides of the root exudates e.g. citrate (Ryan et al., 2014; Zhang et al., 2016)These exudates probably chelated soil micronutrients thus increased their availability and uptake by plants (Pingoliya et al., 2015). Lopez-Bucio et al., 2002, Koreish et al. (1998), El-Shamma et al. (2000) reported that the increased rates of phosphate fertilizers led to concurrent increases in nitrogen uptake and consequently higher grain yields.

It is worthy to mention that seed soaking increased slightly nutrient contents in shoot and seed. In this concern, soaking seeds in $\mathrm{P}$-solution did not increase significantly the nutrient content of plant shoots or seeds except for those amended with P-fertilizer before sowing (MSM). The positive effect of seed soaking was also reported by ElHamdi (1990), Xu et al. (2002) and El-Ghamry et al. (2009) on cowpea nutrients phosphorus and by Payne et al., 1986

There is an antagonism relationship between (phosphorus and zinc) and (phosphorus and iron) absorption by plants and increasing phosphate fertilization leads to a lack of absorption of zinc and iron.

Quality parameters

Table 4 shows that application of P-fertilizer enhanced the chlorophyll content in leaves as well as the protein content in seeds. In this concern, amending soils with $\mathrm{P}$ before sowing seeds seemed to be a most efficient treatment than amending soils with $\mathrm{P}$ after seedling emergence. Similar results were reported by El-Shamma et al. (2000) and Abou Hussien et al. (2002) indicating the positive effect of P-fertilizers on the protein content in seeds.
The effect of phosphorus on the chlorophyll content in plants was also reported by Jiang et al. (2007), Pingoliya et al. (2015) and Chrysargyris et al. (2016). Concerning the effect of seed soaking on the plant quality parameters, soaking treatment increased both the chlorophyll and protein contents except for plants amended with $\mathrm{P}$ before sowing.

Table 3. Chemical composition of faba bean as affected by soaking seed treatments and methods of phosphorus application

\begin{tabular}{|c|c|c|c|c|}
\hline \multirow{2}{*}{ Treatment } & \multicolumn{3}{|c|}{ Shoot } & Seed \\
\hline & Cont. & DPM & MSM & mean Cont DPM MSM mean \\
\hline \multicolumn{5}{|c|}{$\mathrm{N}, \mathrm{g} \mathrm{kg}^{-\mathrm{I}}$} \\
\hline Without Soak & 15.5 & 25.2 & 16.2 & $\begin{array}{lllll}19.0 & 33.4 & 36.4 & 38.0 & 35.9\end{array}$ \\
\hline Soak & 16.8 & 22.4 & 21.2 & $\begin{array}{lllll}20.1 & 33.7 & 36 & 43.7 & 37.8\end{array}$ \\
\hline Mean & 16.2 & 23.8 & 18.7 & 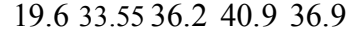 \\
\hline LSD5\% & & & 00 & 0.014 \\
\hline
\end{tabular}

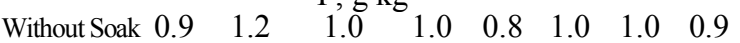
$\begin{array}{lllllllll}\text { Soak } & 0.9 & 1.1 & 1.3 & 1.1 & 0.7 & 1.2 & 1.3 & 1.1\end{array}$ $\begin{array}{lllllllll}\text { Mean } & 0.9 & 1.15 & 1.2 & 1.1 & 0.75 & 1.1 & 1.2 & 1.0\end{array}$ \begin{tabular}{ccc}
$\mathrm{LSD} 5 \%$ & 0.02 & 0.05 \\
\hline
\end{tabular}

$\begin{array}{llllllll}\text { Without Soak 23.4 } & 25.9 & 25.3 & 24.9 & 9.6 & 9.8 & 9.7 & 9.7\end{array}$ $\begin{array}{llllllllll}\text { Soak } & 21.6 & 23.5 & 25 & 23.4 & 9.5 & 10.0 & 10.0 & 9.8\end{array}$ $\begin{array}{lllllllll}\text { Mean } & 22.5 & 24.7 & 25.2 & 24.1 & 9.55 & 9.9 & 9.9 & 9.8\end{array}$ $\begin{array}{lccc}\text { LSD5\% } & 0.05 & 0.01\end{array}$ $\mathrm{Fe}, \mathrm{mg} \mathrm{kg}^{-1}$

Without Soak381.6 $420.9 \quad 352.3 \quad 384.93220 .8194 .8259 .5225 .0$

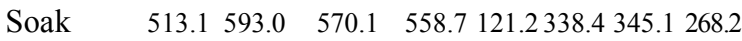
Mean $\quad 447.4 \quad 507.0 \quad 461.2 \quad 471.86171 .0266 .6302 .3246 .6$ $\begin{array}{lll}\mathrm{LSD} 5 \% & 7.82 & 34.48\end{array}$

\begin{tabular}{lllllllll}
\hline Without Soak 46.5 & 57.3 & 65.8 & 56.5 & 43.3 & 37.5 & 63.6 & 48.1
\end{tabular} $\begin{array}{lllllllll}\text { Soak } & 41.3 & 53.2 & 52.1 & 48.9 & 33.6 & 39.4 & 33.9 & 35.6\end{array}$

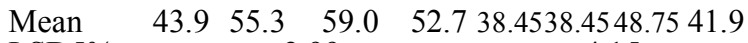
$\begin{array}{lll}\mathrm{LSD} 5 \% & 2.99 & 4.15\end{array}$

Data in Table 5 clarifies soil after harvest as affected by soaking seed treatments and methods of phosphorus application on the studied soil during 2015/2016 season. It is noticed that individual effect of application high significance $\mathrm{K}\left(\mathrm{mg} \mathrm{kg}^{-1}\right)$, while $\mathrm{N}\left(\mathrm{mg} \mathrm{kg}^{-1}\right)$ is significance but $\mathrm{P}\left(\mathrm{mg} \mathrm{kg}^{-1}\right)$ is non-significance. The plant absorbs the elements from the soil and also absorbed the phosphorus added before planting 
with soil settings and added in the way of mixture with soil method (MSM) and phosphorus left the result is added in a way deep placement method (DPM).

Table 4. Quality parameters of faba bean as affected by soaking seed treatments and methods of phosphorus application during 2015/2016 season.

\begin{tabular}{|c|c|c|c|c|}
\hline & Cont & DPM & MSM & mean \\
\hline & \multicolumn{4}{|c|}{ Chlorophyll(SPAD) Fresh Weight } \\
\hline Without Soak & 21.8 & 27.1 & 29.03 & 25.9767 \\
\hline Soak & 22.57 & 27.97 & 26.53 & 25.69 \\
\hline Mean & 22.185 & 27.535 & 27.78 & 25.8333 \\
\hline LSD5\% & \multicolumn{4}{|c|}{1.15} \\
\hline \multicolumn{5}{|c|}{ Protein \% in seeds } \\
\hline Without Soak & 20.87 & 22.77 & 27.5 & 23.7133 \\
\hline Soak & 21.04 & 22.52 & 27.31 & 23.6233 \\
\hline Mean & 20.955 & 22.645 & 27.405 & 23.6683 \\
\hline LSD5\% & & & - & \\
\hline
\end{tabular}

Table 5. Residual NPK contents in soil after plant harvest as affected by soaking seed and the time of phosphorus application season.

\begin{tabular}{lcccc}
\hline & Cont. & DPM & MSM & mean \\
\hline Without Soak & 97.52 & 124.83 & 137.67 & 120.00 \\
Soak & 93.99 & 111.70 & 136.46 & 114.05 \\
Mean & 95.76 & 118.27 & 137.05 & 117.02 \\
LSD5\% & \multicolumn{4}{c}{6.80} \\
\hline Without Soak & 10.91 & 12.99 & 11.79 & 11.89 \\
Soak & 22.70 & 29.74 & 26.07 & 26.17 \\
Mean & 16.81 & 21.37 & 18.93 & 19.03 \\
LSD5\% & \multicolumn{4}{c}{3.27} \\
Without Soak & 351.50 & 474.69 & mg kg-1 \\
Soak & 308.59 & 444.62 & 373.94 & 417.03 \\
Mean & 330.05 & 459.66 & 399.42 & 396.72 \\
LSD5\% & \multicolumn{5}{c}{5.86} \\
\hline
\end{tabular}

\section{CONCLUSION}

In conclusion, soaking seeds in $\mathrm{P}$ solution prior to cultivation seemed to be the most appropriate method for growing broad beans to attain greater growth of faba beans and improve its yield parameters only if the arable soils were amended with P prior to seed sowing. During imbibition, seeds absorb high quantities of water in short time periods, thus increased the free energy status which initiates biochemical reactions prior to germination (Dragicevic and Sredojevic, 2011). This process is associated with exothermic transformations to increase enthalpy (Shafaei et al., 2016). Probably, the increases in the free energy of plant seedlings requires high contents of balanced nutrients to be taken up from soils by the grown plants. Thus, growing soaked seeds in soils of low P content might therefore, decrease the growth of plants, as well as their nutrient contents and quality parameters. Accordingly, the soaked seeds should be grown in soils amended with P-fertilizers before sowing the seeds to attain better plant growth and yield.

\section{REFERENCES}

Abdel-Haleem, A. K. (1994). Growth and yield of faba bean as affected by inoculation, phosphorus fertilization and irrigation frequency. J. Agric. Sci., Mans. Univ., 19 (11): 3563-3574.

Abou Hussien, E. A.; Abou El-Fadl, M. A.; Radwan, S. A. and Khalil, H. M. (2002). Response of wheat and broad bean plants to phosphorus under different soil conditions. Egypt J. Agric. Res., 80 (1): 41-55.
Afzal, A.; Bano, A.; Fatima, M.(2010). Higher soybean yield by inoculation with $\mathrm{N}$-fixing and $\mathrm{P}$-solubilizing bacteria. Agronomy for Sustainable Development, 30 (2): 487-495.

AOAC (2007). Official Methods of Analysis. $18^{\text {th }} \mathrm{Ed}$. Association of Official Analytical Chemists, Inc., Gaithersburg, MD, Method 2007.04.

Becker, M., Dieckmann, K. H., Ladha, J. K., Ottow,J. C. G. (1991): Effect of NPK on growth and nitrogen fixation of $\mathrm{S}$. rostrata as a green manure for lowland rice (Oryza sativa L.). Plant Soil, 132, 149-158.

Chrysargyris, A., Panayiotou, C., Tzortzakis, N. (2016) Nitrogen and phosphorus levels affected plant growth, essential oil composition and antioxidant status of lavender plant (Lavandula angustifolia Mill.), Industrial Crops and Products, 83, 577-586, https://doi.org/10.1016/j.indcrop.2015.12.067.

Dewis, J. and F. Fertias (1970). Physical and Chemical Methods of Soil and Water Analysis. Soils Bulletin No. 10. FAO. Rome.

Diez, J. A., Cartagena, M. C., Vallejo, A. (1992): Controlling phosphorus fixation in calcareous soils by using coated diammonium phosphate. Fertilizer Res., 31, 269-274.

Dragicevic, V. and Sredojevic, S. (2011) Thermodynamics of Seed and Plant Growth. In: J. C. Moreno-Piraján. Thermodynamics - Systems in Equilibrium and NonEquilibrium. InTech . DOI: 10.5772/1435

El-Ghamry. A.M. ; A.A. Mosa and E.M. El-Naggar (2009). Optimum time for phosphorus fertilization on Egyptian alluvial soil. Acta Agronomica Hungarica, 57(3): 363-370.

El-Hamdi, K. H. (1990): Phosphatic fertilization of faba bean grown on calcareous soils. J. Agric. Mansoura Univ., 15, 1529-1536.

El-Shamma, H.A ; A.H. Shahien and S.S. Awad (2000). Studies on the influence of varying soil moisture regimes, phosphorus and potassium fertilization rates on common bean plants green pods and dry seed yield and quality. Ann. of Agric. Sci. Moshtohor, 38 (4): 2473-2490.

Esmail, A.O. and K.K. Miran (2012). Effect of levels of phosphorus, methods of application and their combinations on growth, yield and quality of broad bean in calcareous soil. Univ. of Salahaddin, College of Agric., pp:1-9.

Gomez, K.N. and A.A. Gomez (1984). Statistical procedures for agricultural research. John Wiley and Sons, New York, $2^{\text {nd }}$ ed., $68 \mathrm{p}$.

Hashemabadi, D. (2013). Phosphorus fertilizers effect on the yield and yield components of faba bean (Vicia faba L.). Annals of Bio. Res., 4(2): 181-184.

Henry, L. ; A.E. Slinkard and J.J. Hogg (1995). The effect of phosphorus fertilizer on establishment, yield and quality of pea, lentil and faba bean. Canadian J. of Plant Sci., 75 (2): 395-398.

Hesse, P.R. (1971). A Text Book of Soil Chemical Analysis. Juan Murry (Publisher) Ltd, London.

Jensen, E.S. ; M.B. Peoples and H. Hauggaard-Nielsen (2010). Faba bean in cropping systems. Field Crops Res., 115: 203-216. 
Jiang, H.M., Yang, J.C., Zhang, J.F. (2007) Effects of external phosphorus on the cell ultrastructure and the chlorophyll content of maize under cadmium and zinc stress, Environmental Pollution, 147 (3), 750-756, https://doi.org/10.1016/j.envpol.2006.09.006.

Johnston, A. (2001). Phosphorus Fertilization - Sources and Efficiency. Regional Newsletter, Potash \& Phosphate Institute (PPI) and Potash \& Phosphate Institute of Canada (PPIC).

Koreish, E.A. ; H.M. Ramadan; M.E.E. Fayoumy and H.M. Gaber (1998). Response of faba bean and wheat to bio-and mineral fertilization in newly reclaimed soils. J. Adv. Agric. Res., 6: 20012010.

Lopez-Bucio, J. ; E. Hernández-Abreu ; L. SánchezCalderón ; M.F. Nieto-Jacobo ; J. Simpson and L. Herrera-Estrella (2002). Phosphate availability alters architecture and causes changes in hormone sensitivity in the Arabidopsis root system. Plant Physiol., 129:2 44-256.

Marschner, H. (2012). Mineral nutrition of higher plants. 3rd Edition. Academic press San Diego, USA.

Mathieu, C., Pieltain, F., \& Jeanroy, E. (2003). Analyse chimique des sols: Méthodes choisies. Tec \& doc.

Payne, G. G., Sumner, M. E., Plank, C. O. (1986): Yield and composition of soybeans as influenced by soil $\mathrm{pH}$, phosphorus, zinc and copper. Commun. Soil Sci. Plant Anal., 17, 257-273.

Peterburgski, A.V. (1986) "Hand Book of Agronomic Chemistry" Kolop Publishing House, Moscow (in Russian). Pp: 29-86.

Pingoliya, K.K., Mathur, A.K., Dotaniya, M.L., Dotaniya, C.K. (2015) Impact of phosphorus and iron on protein and chlorophyll content in chickpea (Cicer arietinum L.). Legume Research, 38(4), 558-560.

Pregle, E. (1945). "Quantitative Organic Micro-Analysis" $4^{\text {th }}$ Ed. J. Chudrial, London.

Ryan, P. R., James, R. A., Weligama, C., Delhaize, E., Rattey, A., Lewis, D. C., Bovill, W. D., McDonald, G., Rathjen, T. M., Wang, E., Fettell, N. A. and Richardson, A. E. (2014), Can citrate efflux from roots improve phosphorus uptake by plants? Testing the hypothesis with near-isogenic lines of wheat. Physiol Plantarum, 151: 230-242. doi:10.1111/ppl. 12150

Sa, T. M., Israel, D. W (1991): Energy statusand functioning of phosphorus-deficient soybean nodules. Plant Physiol., 97, 928-935.
Sa, T. M., Israel, D. W. (1995): Nitrogen assimilation in nitrogen-fixing soybean plants during phosphorus deficiency. Crop Sci., 35, 814-820.

Shafaei, S.M., Masoumi, A.A., Roshan, H. (2016) Analysis of water absorption of bean and chickpea during soaking using Peleg model, Journal of the Saudi Society of Agricultural Sciences, 15 (2), 135-144, https://doi.org/10.1016/j.jssas.2014.08.003.

Slaton, N.A. ; C.E. Wilson ; R.J. Norman ; S. Ntamatungiro and D.L. Frizzell (2002). Rice response to phosphorus fertilizer application rate and timing on alkaline soils in Arkansas. Agron. J., 94: 1393-1399.

Snedecor, G.W. and W.G. Cochran (1980). "Statistical Methods" $7^{\text {th }} E d$. The Iowa State Univ. Press, Iowa, USA. soils by using coated diammonium phosphate. Fertilizer Res., 31, 269-274.

Sorour, A. E. (1993). Fertilization of faba bean plant (Vicia faba L.). M.Sc. Thesis, Fac. Agric. Mansoura Univ.

Total chlorophylls content (SPAD): It was assessed in the third leaf of main stem by SPAD-502 (Minolta Co. Ltd., Osaka, Japan).

Turk, M.A. and A.M. Tawaha (2001). Common vetch productivity as influenced by rate and method of phosphate placement in Mediterranean environment. Agric. Mediterr., 131: 108-111.

Turk, M.A. and A.R.M. Tawaha (2002). Impact of seeding rate, seeding date, rate and method of phosphorus application in faba bean (ViciaFaba L.) in the absence of moisture stress. Biotechnol. Agron. Soc. Environ., 6(3): 171-178.

Wen, Z., Shen, J., Blackwell, M., Li, H., Zhao, B., Yuan, H. 2016. Combined Applications of Nitrogen and Phosphorus Fertilizers with Manure Increase Maize Yield and Nutrient Uptake via Stimulating Root Growth in a Long-Term Experiment, Pedosphere, 26 (1), 62-73, https://doi.org/10.1016/S1002-0160(15) 60023-6.

Xu, D., Dell, B., Malajczuk, N., Gng, M. (2002): Effect of P fertilisation on productivity and nutrient accumulation in a Eucalyptus grandis $\times \mathrm{E}$. urophyllaplantation in southern China. Forest Ecol. Manag., 161, 89-100.

Zhang, D., Zhang, C., Tang, X., Li, H., Zhang, F., Rengel, Z., Whalley, W. R., Davies, W. J. and Shen, J. (2016), Increased soil phosphorus availability induced by faba bean root exudation stimulates root growth and phosphorus uptake in neighbouring maize. New Phytol, 209: 823-831. doi:10.1111/nph.13613

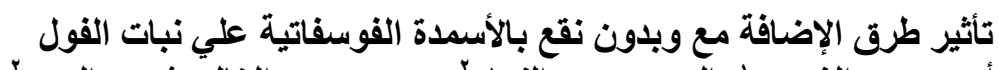

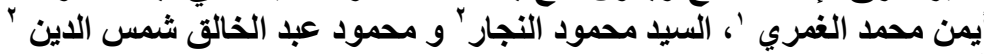

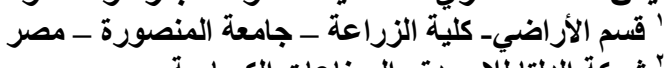

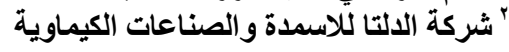

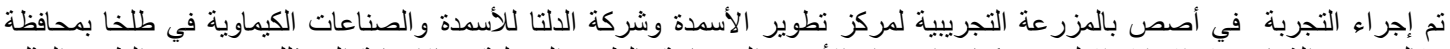

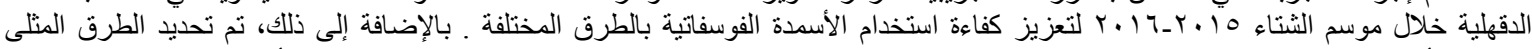

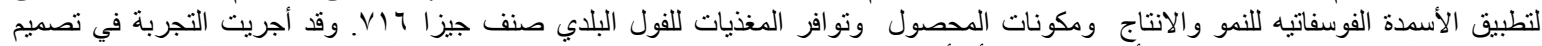

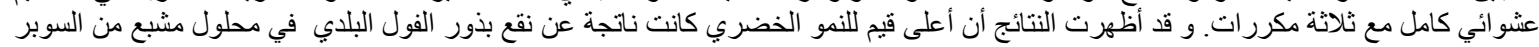

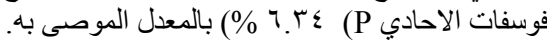

